\title{
AN OBSERVATIONAL STUDY OF ANENCEPHALOUS FETUSES MOUNTED AS MUSEUM SPECIMEN
}

\author{
Uma. B. Gopal *1, Chaitra S ${ }^{2}$, Santhosh Singarapu ${ }^{3}$, Pranav Krishnan ${ }^{4}$. \\ ${ }^{* 1}$ Professor, Department of Rachana Shareera, SDM College of Ayurveda and Hospital, Hassan, \\ India. \\ 2,3,4, PG Scholars, Department of Rachana Shareera, SDM College of Ayurveda and Hospital, Hassan, \\ India.
}

\section{ABSTRACT}

Neural tube defects (NTDs) constitute the most frequently encountered congenital anomalies of the central nervous system. Neural tube defects result from the defective closure of the neural tube during embryogenesis. Most defects of the brain and spinal cord result from abnormal closure of the neural folds in the third and fifth weeks of development. Anencephaly and Spina bifida are two most common types of neural tube defects. Anencephaly also known as exencephaly results due to failure of the anterior neuropore to close. Spina bifida results from defective neural tube closure along some or the entire length of the vertebral column. Antenatal diagnosis of the condition can be made by ultrasonography in later part of pregnancy, since the vault of the skull is absent and estimation of a fetoprotein level of the amniotic fluid. It is advisable to terminate the pregnancy when anomalous condition is diagnosed. Better knowledge of unexpected foetal loss is the promise for better parental counselling and for prevention of recurrences. .To prevents NTD, dietary supplements should be provided to low socioeconomic pregnant females. Periconceptional and 1st trimester folic acid supplementation is of prime importance.

KEY WORDS: Neural tube defects, Anencephaly, Spina bifida

Address for Correspondence: Prof. Dr. Uma.B.Gopal, Professor and Head, Department of Shareera Rachana, Sri Dharmasthala Manjunatheshwara College of Ayurveda, Hassan - 573201, Karnataka, India. E-Mail: drumabgopal@gmail.com

Access this Article online

Quick Response code

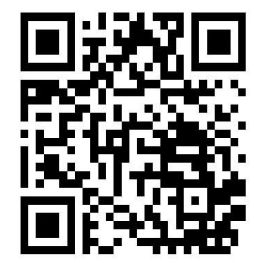

DOI: $10.16965 /$ ijar.2018.120
Journal Information

International Journal of Anatomy and Research

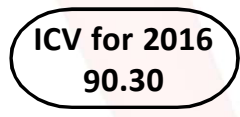

ISSN (E) 2321-4287 | ISSN (P) 2321-8967

https://www.ijmhr.org/ijar.htm

DOI-Prefix: https://dx.doi.org/10.16965/ijar

\section{Article Information}

Received: 09 Jan 2018

Peer Review: 09 Jan 2018

Revised: 17 Jan 2018
Accepted: 07 Mar 2018

Published (O): 05 Apr 2018

Published (P): 05 Apr 2018

\section{INTRODUCTION}

Neural tube defects (NTDs) constitute the most frequently encountered congenital anomalies of the central nervous system. Neural tube defects result from the defective closure of the neural tube during embryogenesis. Anencephaly and Spina bifida are two most common types of neural tube defects. These two account for $95 \%$ of NTDs [1].

Anencephaly also known as exencephaly, which results due to failure of closure of the anterior neuropore. It is characterised by absence of cranial vault, exposed malformed brain (which later degenerates). Such fetuses lack swallowing reflex, therefore, the last 2 months of pregnancy are characterized by hydromnios [2]. Spina bifida results from defective neural tube closure along some or the entire length of the vertebral column. When no tissue is extruded through the defect, it is termed spina bifida occulta. When the defect forms a protruding sac, the term spina bifida cystica is used [1]. 
Anencephaly is common abnormality (1:5000) and 4 times more frequently seen in female than in male [3].

Antenatal diagnosis of the condition can be made by ultrasonography in later part of pregnancy, since the vault of the skull is absent and also by estimation of a fetoprotein levels of the amniotic fluid. It is advisable to terminate the pregnancy when anomalous condition is diagnosed [2].

\section{CASE REPORT}

Four foetal specimen of anencephalies present in the museum of Department of Rachana Shareera, SDMCA \& H, Hassan were selected for the observational study.

Specimen no 1: A male foetus, 12 weeks old. On observation, foetus showed anencephaly along with the spina bifida.

Fig. 1: Anencephalous foetus along with spina bifida.

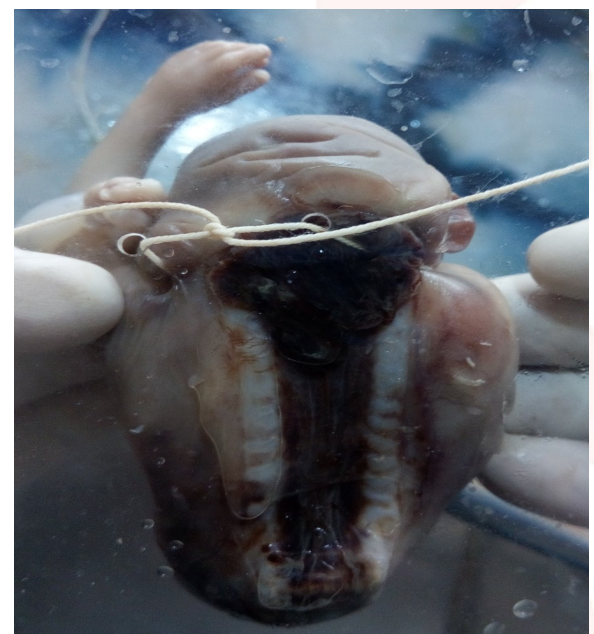

Specimen no 2: A female foetus,14 weeks old, on observation, foetus showed anencephaly with exophthalmos and spina bifida at the level of cervical region.

Fig. 2: Anencephalous foetus with exophthalmos.

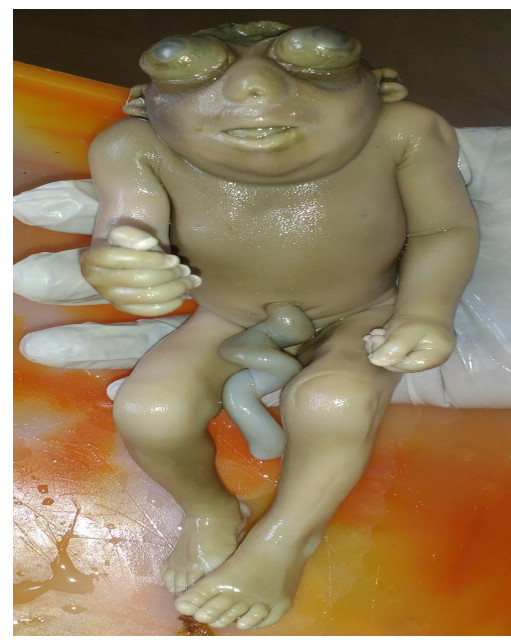

Specimen no 3: A female foetus, 16 weeks old, on observation, foetus showed anencephaly with spina bifida over cervical and thoracic region.

Fig. 3: Anencephalous foetus along with spina bifida over cervical and thoracic region.

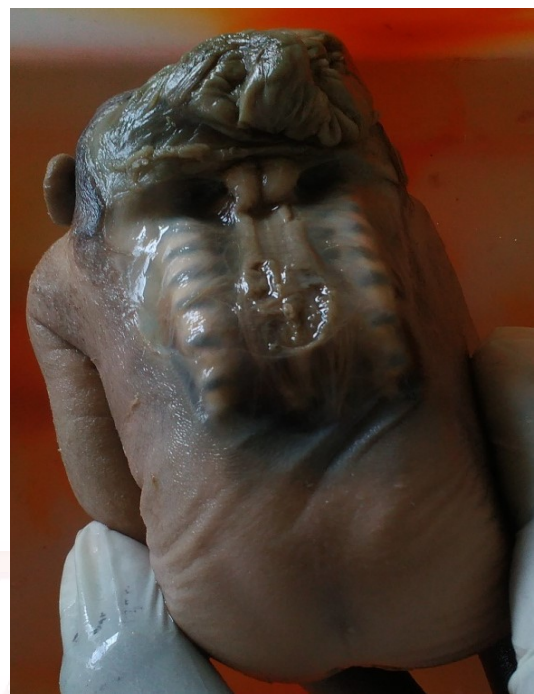

Specimen no 4: A female foetus, 16 weeks old, on observation, foetus showed anencephaly with spina bifida over cervical and thoracic region.

Fig. 4: Anencephalous foetus.

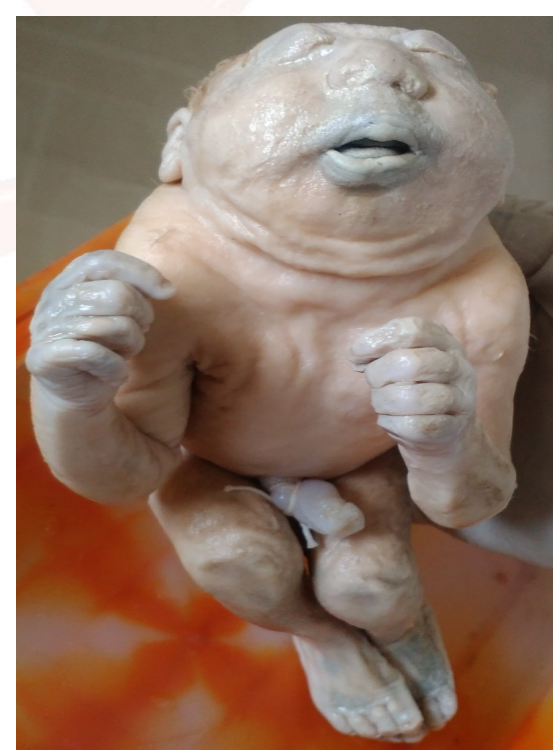

\section{DISCUSSION}

Most defects of the brain and spinal cord result from abnormal closure of the neural folds in the third and fifth weeks of development. The resulting abnormalities in the form of neural tube defects, may involve the meninges, vertebrae, muscles and skin. The birth prevalence of NTDs, including spina bifida and anencephaly, varies among different populations.

The central nervous system (CNS) appears at the 
beginning of the third week as a slipper shaped plate of thickened ectoderm, the neural plate, in the mid-dorsal region in front of the primitive node. Its lateral edges soon elevate to form the neural folds. With further development, the neural folds continue to elevate, approach each other in the midline, and finally fuse, forming the neural tube. Fusion begins in the cervical region and proceeds in cephalic and caudal directions. At the cranial and caudal ends of the embryo, however fusion is delayed, and the cranial and caudal neuropore temporarily form open connections between the lumen of neural tube and the amniotic cavity. Closure of the cranial neuropore is bidirectional, proceeding from the initial closure site in the cervical region as well as from a later forming site in the fore brain that also proceeds in cranial and caudal directions. Final closure of the cranial neuropore occurs at the $18-20$ somite stage $25^{\text {th }}$ day; closure of the caudal neuropore occur about 2 days later [4].

Anencephaly is a neural tube defect (NTD) caused by a failure of closure in the cranial neuropore between the third and fourth week of gestation (23rd and 26th embryonic day), resulting in the absence of a major portion of the brain, skull, and scalp. The brain lacks part or the entire cerebrum, and the remaining brain tissue is often exposed to injury from amniotic fluid [5].

Epidemiology studies demonstrate variation in prevalence rates. The highest incidence is in Great Britain and Ireland, and the lowest is in Asia, Africa and South America. Anencephaly occurs 6 times more frequent in white than in blacks, females are more often affected than males [6]. Anencephalic new-borns are not competent with life so, it is classified as a lethal neural tube defect. Although stillbirth is a common outcome of foetal anencephaly, some affected fetuses are born alive with a rudimentary brain. Lacking a functioning cerebrum, they are incapable of consciousness and of experiencing pain, although the brain stem may support reflex actions such as breathing, and occasionally responses to sound or touch. Some rudimentary brain development is usually present in a small proportion of neonates surviving for a few days [5].
NTDs are considered to be polygenic, multifactorial condition wherein many genes, nutrients, environmental factors including infections, drugs and maternal disease like diabetes individually or in combination play a role $[3,6]$. Hyperthermia, valproic acid, hypervitaminosis $A$, and large number of teratogens produces NTD's. The origin of most NTD's is multifactorial and likelihood of having a child with such a defect increases significantly once, one affected offspring is born. Recent evidence indicates that folic acid (foliate) reduces the incidences of NTD's in certain populations [7].

The preventive measures include diet supplementation with folic acid before pregnancy and in the 1st month. This can decrease both the frequency and severity of the condition. Another measure to be used is the fortification of both wheat and maize flour with folic acid [8]. A secondary line of prevention is to detect the a bnormality as soon as possible during the pregnancy, obtained by the implementation of the program of the prenatal diagnosis. This knowledge helpful for diagnose and treating of neural tube defects [9].

\section{CONCLUSION}

Better knowledge of unexpected foetal loss is the promise for better parental counselling and for prevention of recurrences. Understanding and identifying the risk factors associated with anencephaly in our population, allows approaches to avoid them and thereby lower the incidence of anencephaly in our population. Anencephaly may be diagnosed by transvaginal sonography as early as 11 weeks. The recurrence risk for future pregnancies is $2-5 \%$. Pre conceptual supplementation with folic acid may reduce the recurrence risk by up to $70 \% .1^{\text {st }}$ trimester antenatal check-up of mothers should be made mandatory. To prevent NTD, dietary supplements should be provided to low socioeconomic pregnant females. Peri conceptional and 1st trimester folic acid supplementation is of prime importance [5].

\section{Conflicts of Interests: None}

\section{REFERENCES}

[1]. Csbay L et al. Central Nervous System Anomalies. Annals, New York Academy of Sciences 1998;21. 
[2]. Arushi, Indu Khurana, BD Chourasia's Dream Human Embryology. $2^{\text {nd }}$ ed. CBS Publishers and Distributers; 2012;260.

[3]. Sadler TW. Lang man's Medical Embryology. $7^{\text {th }}$ ed. Williams and Wilkins Publishers; 1995;400-1.

[4]. Sadler TW. Lang man's Medical Embryology. $7^{\text {th }}$ ed. Williams and Wilkins Publishers; 1995;374.

[5]. Shivaprasad GV, Teki Surekha A Study on Anencephaly-Correlation with Maternal Parameters. Int J Sci Stud 2016;5(10):69.48.

[6]. Kondo A, Kamihira O, Ozawa H. Neural tube defects: Prevalence, etiology and prevention. Int J Urol 2009;16:49-57.
[7]. Sadler TW. Lang man's Medical Embryology. $7^{\text {th }}$ ed. Williams and Wilkins Publishers; 1995 p.386

[8]. Bell KN, Oakley GP Jr. Update on prevention of folic acid-preventable spina bifida and anencephaly. Birth Defects Res A Clin Mol Teratol 2009;85:102-7.

[9]. Chandrupatla M, Swargam N. Anencephaly: A Case Report. Int J Sci Stud 2014;2(7):255-257.

How to cite this article:

Uma. B. Gopal, Chaitra S, Santhosh Singarapu, Pranav Krishnan.

AN OBSERVATIONAL STUDY OF ANENCEPHALOUS FETUSES

MOUNTED AS MUSEUM SPECIMEN. Int J Anat Res 2018;6(2.1):5083-5086. DOI: 10.16965/ijar.2018.120 